Essay based on the keynote address delivered at the Economic Commission for Latin America and the Caribbean (ECLAC) in Santiago, Chile, on 29 April 2014 as part of the thirteenth Raúl Prebisch Lecture.

\title{
Development then and now: Idea and utopia
}

\author{
Rolando Cordera Campos
}

ABSTRACT

The crisis of globalization has given renewed topicality to the idea of development as a complex process involving social and institutional changes as well as a variety of democratic learning processes. Placed at the margin of the international academic and political debate, the political economy of development can come back into its own if academics and politicians responsible for the economy are forced to think for the long term. The political economy of development needs to be twinned with politics so that what we understand by the general interest can be reconfigured in pursuit of freedom, justice and democracy. These can be the keys to turning globalization, whose essence is openness and interdependence, into an active agent in the development of national density, something that is indispensable if we are to think critically about reality and, as Prebisch taught and practised, set history on a future-creating course.

KEYWORDS

JEL CLASSIFICATION

AUTHOR
Economic development, globalization, Raúl Prebisch, development models, equality, human rights, democracy, social welfare, right to development, Latin America

$\mathrm{B} 15, \mathrm{~B} 31, \mathrm{O} 10, \mathrm{O} 54$

Rolando Cordera Campos is professor emeritus at the Faculty of Economics of the National Autonomous University of Mexico (UnAM), Mexico City. cordera@unam.mx 
The ills besetting the Latin American economy are not determined by circumstantial or transient factors. They are an expression of the critical state of affairs in our time and of the incapacity of the economic system -owing to structural defects that it has been beyond our ability or our power to remedy-to achieve and maintain a rate of development consonant with the growth of the population and with its demands for a speedy improvement in its standards.

Raúl Prebisch

\section{I}

\section{Introduction ${ }^{1}$}

The purpose of this essay is to take an unconstrained look at the idea of development, now and formerly. Headquartered in this beautiful and endearing country of poets, educators and fighters for democracy and social justice, ECLAC continues to strive to give rigour and soundness to the thinking of Latin Americans committed to collective progress and the constant, ever-renewed affirmation of Latin America in the world as a group of States and nations linked by the idea of sovereignty, but also joined in an innate project of human cooperation to sustain and give meaning to the discourse of changing production patterns with social equity, citizenship and democracy that now includes, as a consistent rider, a bold call to make this the time for equality.

In Prebisch's teaching, these substantive prerequisites for the continent's political evolution are organized around the idea, the theory and the practice of development. Feeding into them are a complex set of economic transformations, new and changing roles in the turbulent environment of the global economy, social movements and long-term commitments to instil power structures with a progressive outlook and constrain them to exercise the necessary care and respect for human rights in an expanding horizon of citizenship.

This historic agenda has never been completed, because that is one of the conditions for preventing the American utopia Alfonso Reyes spoke of from descending into futile illusions and for ensuring that what are pursued are realistic and achievable goals of civic improvement and fair and effective social progress.

\footnotetext{
1 I am very excited to be here. My thanks to everyone who had a hand in this generous distinction; my affectionate gratitude to Alicia Bárcena and my warm respect for those whose intellectual endeavour and keen dedication to development research and thinking have contributed to the great educational and transformative effort called for by Raúl Prebisch, the great heretic, as Furtado would call him, and the members of the ECLAC order of development.
}

An ambitious and consistent innovator, Prebisch dwelt on the need for the legionaries of Latin American development - economists, sociologists, political scientists, and now biologists and environmentaliststo equip and enrich themselves with the exercise of a critically informed intellectual autonomy. His unceasing commitment to finding ways around blockages and labyrinths engaged him in a tireless labour of institutionbuilding. Raúl Prebisch was a man of action when it came to the design and discussion of economic policy, a patient explorer - as well as a bold and restless one - in quest of an authentic and robust Latin American development. He never indulged in ephemeral self-satisfaction, but was always ready to imagine and venture along his own paths of invention and adaptation, not, as Alfonso Reyes would have put it, of "extra-logical" and uncritical adoption or imitation.

His vision still has a contemporary, modern character: the polarity and tension in the centre-periphery global system; the crucial centrality of technical progress and thence of knowledge and culture; dynamic, creative links between external trade and production growth; foreign investment, import substitution, virtuous interdependence; commodity terms of trade as an opportunity, but also a nightmare. The very first requirement, as we have been told time and again in these lectures, is to think critically about reality, do away with self-styled hegemonic thinking, and put history to transformative, future-creating use.

I have drawn heavily upon the reflections of those who have preceded me on this splendid platform, and I am only sorry that I cannot do them the justice they deserve. All occupied and preoccupied by the imperious challenge of development, aware that this can only be achieved by drawing on a public ethos that can give historical as well as practical meaning to democracy, the constitutional State, human rights and justice. Celso Furtado, Joseph Stiglitz, Fernando Henrique Cardoso, Rubens Ricupero, 
Dani Rodrik, Enrique Iglesias, Tulio Halperín-Donghi, Fernando Savater, Aldo Ferrer, José Antonio Ocampo, Danilo Astori, Luiz Gonzaga Belluzzo, enrolled as of right in the legion founded by Raúl Prebisch and those around him in search of Latin America's and the world's best platforms of social and political thought.

When trying to think past the fog brought down by this first great global crisis, it has not been and will not be easy to identify a new forge in which economics and politics, in fusion, can lead us to the outline of new strategies for a development that has gone astray and democracies that are under strain: the keynote ideas or paradigms that have inspired or justified, as the case may be, the different projects for transforming the State and production systems in pursuit of social and economic change have never been neutral.

As Rosanvallon (1989) pointed out in his study of the development of Keynesianism in France, economic ideas, unlike theories in the physical and natural sciences, are not addressed on a homogeneous plane of knowledge. Some political and ideological filter is always present, and it is never innocuous; nor are the presence and action of State bureaucracies, particularly financial ones; social interests and agents; those deriving de facto power from wealth; and influential media conglomerates with a global reach.

Common sense, constructed in and from the media and in the dominant centres of thought and opinion, is not likely to encourage the emergence of new ideas about the governance of the State and the economy. Rather, it acts as a powerful yet ill-defined barrier against them and their conversion into alternative paradigms.

It also serves to support cosmetic revisions or renewals of the predominant schools of thought, which are reproduced not in a linear fashion but through the institutional and ideological enclaves where social conflict and political confrontation are never-ending.

The political and intellectual developments that have accompanied the current crisis, or that it has brought to prominence, provide lessons of particular interest to those of us who work in the privileged global and regional observatory that is ECLAC, especially if what has brought us here is a belief in the pressing need to construct a vision that, without evading or mythologizing the vast structural and mental shifts brought about by globalization, explicitly sets out to build strategies guided by aims of cultural renewal, social redistribution, enlarged democracy and strict yet creative stewardship of the environment.

We are faced with new milestones, complex and tense interactions between politics and democracy, the
State and the market, the economy and society. Initially, financial disaster made yesterday's dogma anathema (global self-regulation and market efficiency), while the powers of time and the world seemed intent on giving a new relevance to what had been seen as an anachronism (the active role of States). The world did not set out from there, though, to use the crisis as a platform for conquering a different future. Rather, those same powers and their offshoots in academia and the media seemed to opt for a new return to the past.

For this and many other reasons, we have and will continue to have a great deal to review and rethink, and we need to do this now, without haste but without delay. We need to recognize that we represent a discipline "shamed" by its helplessness in the face of the Great Recession, as Lord Skidelsky, the great biographer of Keynes, has put it, and then go on to recover, and quickly, a common sense that only the cultivation of history and engagement with criticism can provide.

In Prebisch's words, "a new rationality must be sought, but (...) one not merely based on economic and social objectives but on eminently ethical ones" (Dosman, 2011). This affirmation can be extended to the establishment of a public ethos (Cortina, 2013) that reasserts solidarity as a modern value, as well as the acceptance of a good dose of humility in our exercise of historical and conceptual review and modernization. As Ocampo (2001) has put it: "The idea that 'we already know what must be done' is nothing more than a sign of arrogance on the part of the economics profession (...) the unsatisfactory results of reforms and the existing level of social discontent should —and is - leading many experts to rethink the development agenda."

The political economy of development that we want should show that it is willing to join forces with politics to reconfigure the meaning of the general interest or common good in pursuit of freedom, justice and democracy. Only thus will we be able to return to long-term visions centred on sustained economic growth, the centrality of equity to social equality and the creation of a sustainable democratic citizenship. These can be the keys to turning globalization, whose essence is openness and interdependence, into an active agent in the development of the national density that Ferrer (2010) considers indispensable for resolving the great dilemma of development in a globalized world.

Coupling democracy and economics with globalization has not been and will not be an easy road to travel; what it ultimately comes down to, though, is re-embarking upon the adventure of social change, as in the past, when it was believed that appropriating the 
future to reinvent it through development and planning was not just an "organized fantasy", as Celso Furtado called it, but a realistic utopia.

As he put it: "What characterizes development is the underlying social project. Growth is founded on the preservation of the privileges of the elites, who satisfy their zeal for modernization. When the social project gives priority to the effective improvement of the living conditions of the majority of the population, growth is metamorphosed into development. But this metamorphosis is not spontaneous. It is the fruit of the expression of a political will" (Furtado, 2004).

Schematically, section II of this document deals with some issues considered critical, the aim being to review, update and put into perspective the idea of development cultivated by ECLAC and its thinkers. These issues have to do with the tension between crises, democracy and inequality in the light of the urgent need to restore development as a central concept and process, as discussed in section III. Section IV addresses what is held to be the great modern tripod: rights and the demand for development and justice with a view to emerging from the current global crisis to what is regarded as the great institutional commitment giving substance to the idea of development: the welfare State, which is discussed in section V. Section VI adds an overview, at once critical and constructive, of structural change undertaken in Mexico with the aim of accelerating the globalization of its economy. Lastly, section VII sets forth the main conclusions of the essay.

\section{II \\ Crisis, democracy, inequality: going back to basics}

The current crisis has called into question the globalization that accelerated in the late twentieth century. Whether or not we are on the brink of deeper changes in a global order that could not be constituted as such at the close of the Cold War; whether or not its essential mechanisms and fabrics can be restored on a basis of free trade or capital mobility; whether national economies are capable of dealing positively and productively with the great issue of migration: these are some of the dilemmas surrounding the old tension between economics and politics, democracy, the market and development.

Social conflict, heightened by the crisis, is overshadowing the potential for economic recovery and, as inequality increases, threatens to lead not only to a new discontent in the culture, in this case in democracy, but in what UNDP (2004) warned of a few years ago for Latin America: a disconnect between economics and politics, exacerbated by a heightening of the social question, which is spreading in the form of discontent not only in but with the region's restored democracy.

Because of this, it needs to be appreciated that the relationship between democracy and inequality encompasses a dimension that transcends the economic sphere and belongs, by reason of its importance, to the field of what we might call "State policy"; and implementing or even proposing this means asking questions about the organizational, institutional and fiscal, political and ideological capabilities of States that went through the traumatic shifts of the neoliberal model and are now struggling to turn back into constitutional democratic States worthy of the name.

In these circumstances, reform of the State takes on a structural cast that cannot be dealt with by reductionist expedients, such as minimizing it, or indeed merely enlarging the public-sector apparatus. What is urgent is to rethink the centrality of the State as an institutional whole, as an interface with the rest of the transnational system of States and as a complex relationship between society and power and the ways in which this is constituted and exercised.

The issue of hierarchies and of the constitution, exercise and renewal of power is inseparable from the other two key aspects of any political economy: the division of labour and the distribution of the fruits of the social effort involved in production. Social coordination ultimately depends on how the unfolding of this central triangle of societies, markets and States is dynamically approached. The relationship is always in tension, on the verge of instability, and this has been heightened by the advance of globalization, economic and otherwise.

For now, what we can say is that we still have politics and the pacts that can be forged through it to seek means and mechanisms whereby these tensions can be prevented from turning into insoluble contradictions 
and national formations from dissolving into the global maelstrom. Having invoked politics in this way, we may add that an expressly equality-oriented politics needs to be cemented in a civic culture and a public ethics consistent with its aims and motivations, if it aspires to be stable and lasting. The crisis of equality is an all-encompassing social fact and not just a matter of incomes, access or opportunities.

How, then, are we to build societies that are more democratic, egalitarian and supportive? Can democracy endure in conditions of acute inequality and poverty? How far is it possible to speak of democracy when economic and social inequity is being maintained and reproduced? How can we achieve substantive changes that help to reduce levels of inequality and exclusion and ensure universal access to and exercise of social rights?

Asking these questions is not a mere intellectual exercise. Latin American social and political thought is entangled in them. After years of democratic recovery and almost two decades of economic growth, inadequate at first and then fairly high and in some cases steady, albeit without significant changes in income distribution, the problems posed to democracy by inequality are still being evaded.

It could be said that inequality is becoming a culture, not the culture of poverty that anthropologists studied, but one of concentrated wealth, or indeed satisfaction, as Galbraith (2011) would say. Apart from complicating modern political designs, this represents a head-on challenge to the ethical and political standards and forms that ought to flow from democratic development.
This could yield a first response to our questions: social cohesion is the fruit of societies' democratic development, but it has also become a precondition for Governments to renew their legitimacy and for democracy to engage the participation and support of citizens. Cohesion, a primary condition for a promising role in a globalized world, is suddenly coming under the crossfire of the democratic call for redistribution and the demand for balances and incentives to accumulation and dynamic forms of competitiveness to hold and win ground in the global marketplace. From these tensions it is just a step to subjecting sovereignty, without prior warning, to new and exorbitant requirements against which, on the face of it, there is no appeal.

This is why the relationship between democracy and inequality needs to be viewed as an equation that has to be resolved positively in favour of equality, and as a prerequisite for politics to produce governance based on legitimacy. Whence it is that in modern societies, or societies seeking to be modern, the dialogue between development and equality ceases to be a product of chance or natural laws and becomes a political issue. This is a severe test for the categorical imperative of democracy that Fernando Henrique Cardoso spoke of.

In the face of these dilemmas, the economy has to evolve into a political economy of development inspired by the current, modern, global equivalent of the moral sentiments of Adam Smith, so that development can be restored.

\section{III}

\section{The topicality of development}

As a process of social, political and economic change, development requires properly functioning institutions, but it also entails a basic restructuring of values and attitudes. Again, the structural hindrances to such change can only be dealt with by an active platform of designs and strategies that disrupt the stability those hindrances create, so that the end result is political and institutional configurations capable of channelling the energies released by economic and social change - and none of this can be guaranteed in advance.

Modern development, and particularly that which began after the end of the Second World War, quickly unfolded into a complex and diverse institutional and political process that is now inseparable from the aspiration to create a universal rights regime. This idea, in turn, draws upon the concept of comprehensive fairness, because if the equality held out by democracy is confined to laws or the polls, it is wholly inadequate to the task of securing and extending social justice. Development envisaged as the creation and expansion of rights; rights understood as justice and freedom; politics conceived as action and an unfailing commitment to the democratic code: these are the cornerstones of a new agenda and a reformed macroeconomy for development and equality. 
At ECLAC, there has rightly been discussion of the different connections between macroeconomics and development economics. These relationships are at the historic core of ECLAC thinking. It is not redundant, however, to recall what Ros (2013) warned of: that development economics, like the economics of growth, "was born macro", and economic growth itself should be seen as a "process of structural change rather than of mere factor accumulation cum technical change."

What the crisis makes imperative, then, is for us to adopt a macroeconomic policy for development and not just for financial or price stabilization, as has been pointed out by Moreno Brid (2013), among others. By focusing on variables such as sustained economic growth and employment, this macroeconomics will have to induce larger strategies and specific, broad-spectrum policies explicitly aimed at promoting social redistribution and restoring the aspirations to equality that inspired the construction of social States.

As ECLAC (2012) pointed out in its second approach to the subject of equality, and as Ocampo
(2011) has explained, an unavoidable condition is the implementation of new production patterns that drive structural diversification and open the way to a dynamic performance capable of sustaining and being combined with objectives of equity, universal rights and expanded citizenship.

Amartya Sen (2003), for his part, has stressed that the concept of development cannot be confined to rising gross domestic product (GDP) or personal income, industrialization, technological progress or social modernization. These are important and often crucial attainments, but their value needs to be gauged by the effect they have on the lives and freedoms of the people who experience them. The development as freedom proposed by the Indian Nobel laureate needs to be extended to development as equality - a complex and even capricious continuum that must not be subjected, however, to arbitrary interruptions dictated by poorly perceived and worse understood economic or financial contingencies, or by concentrated, unconcealed and brazenly asserted class and power interests.

\section{IV}

\section{The modern tripod: development, rights and justice}

The "right to development" predates the current wave of human rights universalization. It is increasingly clear, however, that modern development is inseparable from the aspiration to create a universal rights regime. Only in this way, according to the United Nations, can civilization give real effect to the old dreams of the Enlightenment and the commitments of today's democracy.

The idea of development as progress, as being "up with" what is deemed most advanced, is as old as modernity itself; it forms part not only of classical social science thinking but of the international political experience of the last two centuries. It is no chance that in 1776 Adam Smith, the founding father of economics, gave his most famous work the title Inquiry into the Nature and Causes of the Wealth of Nations.

Concern with this core process of modernity did not become universal and strategic, however, until the second half of the twentieth century. Before that, it only formed part of the arsenal of statesmen in the "closed circle" of powerful nations. It might be said that what was at work was an ethnocentrism without solid foundations, but with an effective rhetoric that encouraged unrestrained pride and selective cosmopolitanism: the "white man's burden" that Kipling spoke of. These configurations of exclusion underwent their first major reverse with the First World War and its aftermath of economic crises and democratic upsets, being overwhelmed in several places by variants of fascism and other totalitarian tendencies.

With the Second World War, the world experienced a great historic turning point: although the conflict was tremendously destructive, it also proved to be a giant "blender" of human cultures and experiences. In more than one sense, it was the first great mass experience of globalization that brought people from everywhere into contact, taking them through territories hitherto unknown to the average citizen, and introduced whole populations from less developed regions into what we would now call modernity.

True, this took place by way of the most violent destruction imaginable, but its lessons were assimilated by emerging or developing elites and were quickly given substance in demands for decolonization, material 
improvement, national independence and social progress. The right to development began to be asserted as a universal demand, and the autonomy of States and the sovereignty of nations as indissoluble components of the new order, whence the importance of the 1955 Bandung Conference, as it was the first time the notion of a "third world" spread around the planet as a leading idea.

Combatants from the advanced world and their families, whose memory of the interwar crises had been sharpened and enhanced by the painful experience of the conflagration, began to regard social protection and the active presence of the State as a collective and individual right that not only had been acquired, but was enforceable. Thus, starting with the centres of the new international system that arose from the war, there was a rational and political (re)discovery of the centrality of development which, to be that, would have to be accompanied by social equity and welfare.

In Latin America, under different conditions and with different perspectives, the dream of development also began to be lived out: State-directed industrialization and import substitution; urbanization, emerging middle classes and mass demands for inclusion; new ways of engaging with a global economy that was being reshaped: all these were part of the arsenal of policies and visions promoted by Raúl Prebisch and his colleagues at ECLAC, whose arguments sought to combine economic rationality with historical necessity via politics and State action, tasks whose crucial importance to economic evolution is now being reaffirmed.

Without being politically and socially centre stage as it is now, democracy was viewed as the institutional and social participation platform that could productively forge a dynamic interdependence between a State with new demands and a society that was changing and seeking new forms of sovereign affirmation vis-à-vis the rest of the world.

Thus, the whole planet gave itself over to the explicit quest for economic growth, as this was considered an indispensable factor in social well-being and the consolidation of democracies. With the triumph of the Chinese Revolution and the independence of India, it seemed that a substantial portion of the world's population would be able to realize these expectations, not only in terms of material progress for all, but by harnessing national capabilities to map out innovative historical paths, including some that were radically different from those hitherto acknowledged as successful.

The ability of the Soviet Union to take a "leap forward" amidst the great depression of the 1930s and withstand the Nazi invasion helped to turn development into the leading idea of the world that was emerging. A cornerstone of this effort was planning, which, when taken up in pursuit of development and post-war reconstruction, lost its centralizing rigidity and began to be seen as a feasible way of pursuing new combinations between State and market and implementing a creative and sustainable mixed economy.

In these circumstances, "Prebisch called for 'an intelligent regime,' or 'smart State.' While the State must support industrialization, the economy as a whole must remain private sector-led in order to prosper" (Dosman, 2001). Excessive State intervention was therefore as damaging as a naive acceptance of the doctrine of comparative advantage. "Don't stifle the private sector," Prebisch warned. A healthy private sector and investment climate were essential for economic success and a wise investment strategy.

When the Cold War made ideology a determining factor in global politics, development too began to be seen as a strategic variable in the bipolar confrontation, being presented as an alternative to revolution and a more effective and gradual way to achieve a redistribution of income and wealth. Paradoxically, it was in the heat of this conflict that many countries experimented with routes towards economic and social progress that aimed to reap the best of two experiences presented at the time as incompatible alternatives.

The "third ways" of those years were not very effective, but the idea of using and exploring traditions and idiosyncrasies as platforms and starting conditions for economic development stuck in the historical and institutional memory. Now, amidst the storms of globalization and its crisis, it demands a central place in the inventory of development institutions and policy options. This was descried, furthermore, by Prebisch, the social reformer and tireless pioneer of planning and the mixed economy (Halperin, 2008).

For decades, the world developed in a frenzied equilibrium of mutual destruction. The reigning paradigm was full employment and social protection, and in the developing world, sustained economic growth and industrialization were seen as the paths towards platforms of progress embodied in welfare States. Regular State interventions in economic processes and decision-making; heavy use of external assistance, lending or investment funding; protection and even creation of fragile local industries: all this and more was brought into play during those years under the banners of growth and a rapid move towards activities with the highest possible value added.

The accumulation of physical capital and productive investment, together with the wider industrialization of 
economies and rapid urbanization of societies, were the main drivers of the great transformation in the second half of the twentieth century. Political effectiveness and sustained material creation were placed above what we would now call sound policy. The mission was expansion, while the distribution of the fruits of growth and economic efficiency (micro or macro) were seen as side-effects of the overall process.

The outcome of this development effort does not fit the bleak myth that would later be propagated. There were mistakes and excesses but, essentially, these were times of rising production and social change; and while the predominance of corporatist forms of social control and participation squeezed democracy and opened the way to all kinds of abuses, corruption and concentration of wealth and power, it is also true that the scope for expanding the spheres of social reproduction increased and was able to bear fruit in the form of goods and institutions.

Years later, with the upheavals of the late twentieth century, which can be summarized as the implosion of Soviet communism and the globalization of finance and, to a lesser extent, of production and trade, a radical paradigm shift occurred. Instead of full employment and social protection, the priorities were the fight against inflation, financial stability and the reduction of State commitments to social welfare and justice. All this was presented as the price of entry to the new globalized world of the unified global market and representative democracy: over time, the new order promised by President Bush after the first Gulf War was to become more of a working hypothesis than an actual development path for international society.

In a number of countries, the ideas of adjustment, external debt payment and the review and rolling back of the State were set in stone as immutable criteria and policies, consistently with what would later be called the Washington Consensus. There thus occurred a profound, and to a large degree passive, economic counter-reform of the State that would significantly affect the economic policy core of the State itself.

Rather than a development that was "elusive", to use the term employed by Wolfe (1976), or erratic and declining like that experienced in the 1970s with its fluctuations, hiatuses and "stagflation", what the world began to experience in the last decades of the twentieth century was a loss of direction, in terms not just of growth rates or macroeconomic stability, but of those values and criteria that drove the great vision of a development understood as expanded rights and social change.

Thus, with its catalogue of recommendations for "getting back to basics", which in this logic is the centrality of the market, the Washington Consensus sought to redesign the profile of the world and introduce a new global order. Its prescription was underpinned by the vision of an untrammelled, and purportedly universal and rational, market economy that reduced the State to a minimum, to the point of turning it into a purely instrumental entity.

This effort to "correct" what were held to be excesses and waste in the State and the tasks it performed was carried so far, as was the revision of ideas and projects, that it even encompassed the removal of the idea of development itself from the map of international priorities. However it may have been understood in the centres of international power and ideas, development always means change and disequilibria, whereas the prevailing terms of reference were those of equilibria, or at best of comparative statics.

In 1986, however, in what can only be called a cruel irony of world history, in the very eye of the hurricane of the financial crises heralding the arrival of the globalizing whirlwind, the right to development was successfully adopted by the United Nations as one of the inalienable human rights. Development, it was affirmed, was the realization of all the civil, economic, social and cultural rights contained in the Universal Declaration of Human Rights. This was followed in 1993 by the proclamation of the right and duty of States to formulate national development policies aimed at constantly improving the welfare of the whole population, ensure equal opportunities for all in access to basic resources, education, health services, food, housing and employment, and bring about fair income distribution.

The discords triggered by the great global change that was beginning clashed with the logic of development, with its mission of identifying and giving political expression to the most heartfelt demands of planetary majorities that the other great disintegration unleashed by the Second World War had set in motion. Bobbio (1991), the great thinker of Turin, spoke and thought about this with remarkable foresight and proverbial acumen. He held that acknowledgement and protection of the rights of human beings are the foundations of modern democratic constitutions. Peace, in turn, is necessary for the recognition and protection of human rights, both within States and in the international system. At the same time, democratization of the international system, which is the only way to realize the ideal of "perpetual peace" in the Kantian sense of the term, cannot advance without a gradual extension of recognition and protection of human rights over and above States. 
According to Bobbio (1991), "Human rights, democracy and peace are three essential stages of the same historical movement. If human rights are not recognized and protected, there is no democracy, and without democracy, the minimum conditions for a peaceful resolution of conflicts do not exist." It might be said that the right to development is underpinned by economic, social, cultural and environmental rights, which, notwithstanding the difficulties of fixing them in time and space, should be seen as rights that answer to the "global" values of equality, solidarity and nondiscrimination. Furthermore, as argued by the United Nations, they should be understood as universal, indivisible and progressive, as well as interdependent with civil and political rights. These socioeconomic, cultural and environmental rights refer to goals and aims whose fulfilment depends on the respective capabilities of economies and States to give them not only reality, but sustainability, whence the insistence, in certain circles and power groupings, on seeing them primarily as "programmatic rights" whose fulfilment depends on financial viability or the economic situation.

However, their value lies rather in the fact that they define a legal and institutional system that helps to entrench ethical attitudes which are increasingly integrated into collective purposes and thence into economic and political decisions intended to meet needs, reduce inequalities and protect the environment.

Recognizing economic, social, cultural and environmental rights as an indissoluble part of the demands of legal and political citizenship, claimed by the West as a triumphant agenda, raises the issue of the "third" citizenship, the social one, studied by Bottomore and Marshall (2005). Its realization depends not only on the generation of adequate material and institutional resources, but on the way these are distributed, and also on this indivisibility of rights becoming established as an essential reflex of States and societies.

This is the essence of the social density democracies can achieve, and on it depends their quality and duration as a fundamental political order. Thus, the evolution of citizenship in and with globalization could shift from the elementary demand for democratic and civic rights and freedoms towards social participation in the construction of political economies organized for equity and equality, not just by their level and rate of growth, but by the political and ethical framework of demands that could be constructed around their centrality. The right to development would then turn into real development of rights.

Yet globalization, incomplete in scope and content, and now in crisis, is far from having yielded the hopedfor results. "Despite the efforts made by the countries of the region, the results of the new development patterns have been unsatisfactory in economic and especially in social and environmental terms. For a large part of the population, this situation is compounded by the fact that people are often unable to exercise their rights as citizens. At the legal and political level, this is manifested in a fundamental inequality in terms of access to the justice system and in the population's lack of involvement in political decision-making. In the economic and social spheres, it takes the form of inequality of opportunity, job instability, low incomes, barriers to social mobility (particularly for women), a disregard for ethnic and cultural diversity and a lack of protection in the face of misfortune" (ECLAC, 2000).

If the right to development is inseparable from social justice, it can also be seen as a fundamental citizen right and its realization is (or ought to be) a priority for States, which is why autonomy and the ability to decide on their own patterns of economic development and social distribution need to be recognized as a universal right of nations, as do the ways they choose to participate in the global market and economy.

Equality, its extension to unfamiliar ways of life and expressions of culture, its link to democracy and broader social participation constitute the great extension of development, the outlook and ethical mandate that ECLAC has offered us. This is also, or should be, the future of States reformed in pursuit of the general welfare.

\section{V}

\section{Welfare States: the great historical commitment}

The ominous circumstances of the present should lead to a reappraisal of the terms of the strategy that led to the crisis. Financial innovation conceived of as a "big bang," the culture of greed and the enthronement of the most extreme possessive individualism are some of the things whose excesses now drive the rediscovered need for their regulation. Together with this, the requirement for strong, dynamic fiscal States is unavoidable: 
only thus will the effort to recast the combination of economic growth and social stability be possible of attainment.

Now, in the face of the disruptions of globalization, which have become a far-reaching crisis since 2008, the role and character of the State in economies is being (re)discovered, as is the urgent need to establish new and more effective forms of connection between the economy and society, with an eye to the way globalizing structural change and its crisis have brought the social question to a head. This is the contention of recent publications by ECLAC (2010 and 2012), arguing and recommending that "the State has to be provided with more capabilities to redistribute resources and promote equality. We are talking about a welfare State, not a subsidiary State, which can advance towards a tax structure and transference system that privileges social solidarity." This is a reaffirmation of the centrality of politics and the State in forging social covenants that are both wide-ranging and deep and in reforming the State and endowing it with effective social promotion and coordination capabilities for the purpose of politics.

The return of the State via its own reform and the expansion of democratic politics will certainly remain subject to the constraints resulting from global and national history and from the specific, idiosyncratic experiences of national formations. A dialectic arises: in the face of "too much State," the libertarian demand for affirmation of individuality and autonomy; in the face of an excessive concentration of politics in parties and parliaments, the new political, ideological and, in a broad sense, cultural conceptions thrown up by globalization and the end of bipolarity: civil society, human rights as a universal mandate, democratic cosmopolitanism, global citizenship.

On the other hand, though, the warning issued by the great Polanyi (1992) in his analysis of the collapse of the first phase of globalization still holds true: if the market sets out to subordinate society, it will end up destroying its own foundations. "Our thesis is that the idea of a self-adjusting market implied a stark Utopia. Such an institution could not exist for any length of time without annihilating the human and natural substance of society."

The role of a social State capable of generating technological and institutional externalities without reneging on its historical commitments is fundamental and non-contingent in this whole process of restoring growth and recentralizing development. The new State reform agenda has nothing to do with ideas of a tabula rasa or an impossible return to the past. It is meant to be the outcome of a recapitulation of concepts and experiences, a renovation in which history illuminates a new course that leads to a project of social inclusion and democratic consolidation.

The reform of the State that the age requires if it is to embark upon a fundamental shift needs to pivot on social reform of the State itself. This cannot be reduced to meeting specific demands for changes in the use of resources or institutional configurations; to be a component and catalyst in an effective and radical "reform of the reforms," the State needs to concentrate on rebuilding basic social fabrics and processes, and this in turn implies a redistribution of power and a radical readjustment of relationships and weights between spheres of the economy and their command over the allocation of resources and the distribution of income and wealth, as well, no doubt, as in the sphere of political and administrative power and in the division of labour within the State itself.

Consequently, there is an unavoidable need for strong, dynamic fiscal States. Only thus can the delicate and fickle combination of economic dynamism with social and macroeconomic redistribution and stability be attempted. As ECLAC (2010) has put it: "Equality of rights provides the normative framework and the basis for social covenants creating more opportunities for those who have less. The equality agenda requires that covenants should be rethought in order to create institutional policy consolidating a democratic and participatory order (...) This agenda includes the construction of a far-reaching economic and social agreement whose ultimate expression is the fiscal covenant. This requires a tax structure and a tax burden that strengthen the redistributive role of the State and of public policy in order to guarantee thresholds of well-being."

From this perspective, the structural change implemented in the late twentieth century needs to be revised with a view to reappraising economic policy and a number of the immovable certainties on which its discourses have been based. In the face of the dictatorship of financial adjustment and fiscal balance, interpreted unequivocally as "zero deficit", it is possible to imagine new ways of structuring national States, other combinations between external opening and induced domestic development that, without giving up on external trade and interdependence, bring to the fore the functional but transcendental notion of development as freedom and equality. 
Going against the orthodoxy, Fernando Fajnzylber (1992) argued that Latin America required an internationally competitive industrial system, but in a context of equity.

In the face of the ongoing crisis and the difficult recovery now in progress, normality needs to be revisited in the light of the harsh experience of these years, although returning to normality means more than restoring growth rates and bringing the production system out of its recession; it means going back to a different "normality" (Anguiano, 2012).

Experience allows and requires us to look further than this. The need today is to make the social question the starting point when reconfiguring goals and visions for the macroeconomy and development. This new inversion of functions may not only prove useful for political stability, but become a renewable source of renovation and enhancement of democratic legitimacy and the State. Conceiving of social policy as an indispensable rather than residual component of democratic development could thus become a civilizing mission.

"Social justice, let it be said again, is inseparable from the right to development," argued Carpizo (2012), a splendid dean of the National Autonomous University of Mexico (UNAM); "the idea of social justice has not become a dead letter (...) The special strength of the concept of social justice lies in the fact that, besides its legal and constitutional meaning, it is impregnated with a sociological character and, in particular, with a sense of equity." It is a citizen right and its realization should be a priority for States, in and beyond the crisis.

To spell it out, the opportunity to place democracy among development objectives seems to be the surest way, albeit perhaps the most arduous one, to render feasible the aspiration (reinvigorated by the changes in the world) of economic progress with greater democratization and social equity with a view to equality. This being so, it is worth reiterating the vital need for a renewed acceptance and appreciation of national dimensions in order to engage with, not exorcize, global ones.

As the Spanish philosopher Adela Cortina (2007) has put it: "The democratic state, an ethical economy, and active citizenship form the tripod on which a developed society is sustained. The philosopher's stone of the new times lies in structuring the endeavours of these three powers - political, economic, and civic."

Conflict with the State has also been a persistent feature of the tradition of thought founded by Prebisch. From the very conception of the modern State to the evaluation of its different forms of intervention, the State is never the last resort for ECLAC, but nor is it the only one, whence the conceptual and practical difficulty of struggling with it, since ultimately it is the relationship between society and power. The saga is a long one: from proto-developmentalism to the mixed economy and innovative planning; from the great project of transformation, development and integration to the constricted State and a relationship cut short by the sheer violence of dictatorship. This provided the impetus for the grotesque ambition of a radical, "revolutionary" reform of the State to remake the present via a misleading rewriting of history: the golden age of a minimal State and an economy of perfect competition that would leap to participate in an illusory unified global market: a false dawn.

Now we are going to find out what lessons have been learnt from decades of conflict, penury and adversity; the difficulty, meaning a linearity the State has to get over, needs to be left behind so that the complexity which is inseparable from globalization, as well as the complexity which is an unavoidable feature of a plural, diverse society that has made democracy the lingua franca of politics, can be fully accepted. Politics, in turn, needs to incorporate into its semantics the dilemmas and constraints issuing from globalization and its "perplexities," as Fajnzylber liked to call them.

This complexity is extended and compounded when it comes up against and is recognized in a structural heterogeneity that globalizing change has been unable to modulate. What it is managing to do is create new hordes of the excluded, together with angry demands for inclusion that are centred increasingly on cities and less on the countryside, directly challenging the purportedly democratic State and calling for representativeness and participation consistent with an egalitarian message that does not end at the polling booth, one of a State refounded by the creation of universal welfare systems, whence the stand-off that encapsulates the current challenge: awkward States and democracies, in a complex and motley social context, torn apart by inequality.

What is needed is a fresh approach to the State that accepts the need for it and for power in general, while recognizing the idiosyncratic stamp of histories, social structures and State configurations that give meaning and character to the two hundred year-old adventure of Latin America, where the idea of development is once again becoming the restless development of ideas. A great deal remains to be done to give substance to the change that now, under the labels of democracy and equality, can be claimed as indispensable. In the first place, it is essential to have a system of decisions and 
priorities, sequences and coalitions that serve to govern it and give it an explicit redistributive stance.

Furthermore, a process like the one outlined calls for effective mechanisms to detect errors, shortcomings and inadequacies and correct them in time, accepting that leadership can be fallible and that a plethora of contingencies always accompany economic and social change. What is at stake is not so much avoiding failure as failing and then trying again in order, as Beckett put it, to "fail better."

"The attempt to influence the forces of development," asserted Prebisch (1963), "involves a design that is far-reaching in terms both of time and of scope. It

\section{VI}

\section{A point of view}

To end, perhaps I may be allowed to venture a brief summary of recent Mexican experience. A frontier country, Mexico may be seen as the "far north" of this far West of ours, as the learned French ambassador Alain Rouquié saw us. The country committed itself heavily to a vertiginous structural change that would carry it rapidly into the new worlds promised by the globalization of the late twentieth century. Mexico's story of its "great transformation" into an open, market-based economy suggests many lessons to be learnt and much to be amended, and in some cases mended, and little to boast about, except society's remarkable willingness to live prudently under the storm of change and give further proof not so much of resignation as of its ability to overcome adversity and seek to affirm the idea of development as a national endeavour.

After almost 30 years in which the State and important and powerful groups in society have looked for a different way of growing and developing, Mexico's political economy is suffering from a crisis of vision that distils the results of poor economic performance and social implications that are discouraging and damaging to that bare level of cohesion required for stability and development. This crisis, in turn, has been feeding into and upon the various social and political failings that have accompanied the structural changes dating from the closing years of the last century and are now viewed as a fearsome combination of anomy and unrestrained criminality. requires not only changed structures, but also changes in outlook, approach and form of action. But are such changes feasible in our countries? When this question arises the response is often a feeling of scepticism that discourages action. But it has to be done, because there is no other way out."

The aim, then, must be to create new economic, institutional and intellectual capabilities, new powers of historical and sociological imagination, in order to adapt global technology and make openness work for us; to nationalize globalization, in other words, something that we in Mexico have put off, leaving the task for some undefined future.
A review of the strategy followed is urgent and necessary and needs to start by questioning the economic policy adopted, whose results hitherto have been very slow growth in economic activity, progressive loss of economy-wide potential, with half the population in poverty and jobs that are not only insecure but ill-paid, falling far short of what is needed by the large and growing number of young people and young adults who embody the country's social and demographic change of recent years. Again, consideration of the democratic structure in operation since the late twentieth century raises the question of whether the forms of representation and government of the State that have been put in place are what is needed to channel the redistributive and developmentalist demands that are looming.

The reforms altered customary practices and the formats and routines of economic calculation, but the dislocations they triggered were not internalized by the emerging social and productive fabric, and they resulted in a greater weakening of the State, whose failings, apparent or invented, served to justify economic reform at any cost and then political reform in which nothing but votes counted. There was a State-led acceleration of social and economic change, but too little was done to modulate it, temper its inevitable dislocations and protect the weakest sectors, regions and social groups.

The achievements of this change are not to be gainsaid: in less than 20 years, Mexico became a major 
exporter of heavy and medium-heavy manufactures, with a powerful industrial base for automotive and electronics production and export. The country's total sales abroad quintupled, and it left behind its virtually complete dependence on a single export product, crude oil.

During these rapid shifts in its trade structure, Mexico attracted considerable amounts of foreign direct investment. The country very quickly became one of the top three trading partners of the United States and came on to the world trade scene as a new and attractive major league player.

It can also be taken as read that, slow as it was, political reform ultimately yielded substantial benefits. The chambers of Congress diversified their political and ideological content, reproduced plurality and gave a new face and hue to the political system that resulted in an active and activist multi-party system. Furthermore, the constraints on a federal system that had always been trammelled and distorted by the central authority were lifted, and the country embarked upon a still unfinished phase of breakneck, almost savage regionalization and decentralization that despite everything has become a source of plural political power exercising a decisive influence within the current national State.

As against this, the question must now be asked as to whether a country of Mexico's economic size, with all the wealth that has been generated and accumulated, with institutions and knowledge so laboriously built up, can afford the luxury of undergoing and reproducing a "stabilizing stagnation" like the one that has become established, along with the levels of inequality and poverty that characterize it. Beneath these discords, there has been a persistent inability to productively link a transformed demography, now dominated by young people and young adults in urban areas of an age to work and study, with a likewise transformed, open and diversified economy, but one that for more than three decades has been unable to generate the jobs and education opportunities needed to absorb the population productively.

The Mexican journey has included excesses and mistakes, both economically and socially, and in ideas about change and the best ways to govern it and secure a good outcome. The main barriers to the necessary transformation, in Mexico and elsewhere, have come from the fundamentalisms imposed in the management of economic policy, which infected important power groupings as well as sections of public opinion. The dogma of maintaining supposed macroeconomic equilibria at all costs, with the elementary external and internal constraints this imposed, led the political and economic elites to support policies and actions driven wholly by the orthodox versions of how these equilibria should be met and maintained.

It needs to be stressed that poor long-term economic performance is not only or mainly the effect of imbalances in international markets. It should rather be understood as an outcome of political and economic decisions that have ignored other "fundamentals," such as the need for sustained physical investment in pursuit of long-term growth, an industrial policy aimed at diversification and the creation of new production chains to appropriate external revenues, and anti-poverty measures and consistent reduction of inequality as core areas of State concern and action.

What must be at the top of the agenda for Mexican economic development is to reconfigure its basic functions and make employment a central, unifying goal of a strategy for growth with and for equality. The relative historical stagnation affecting the country of revolutions and nation-building against the grain of the supposedly universal mandates of history can only be overcome by setting a new course in which means and objectives are recombined and consideration is given to the vital need for new forms of social and political participation in State deliberations and decision-making. Reaching higher platforms of cooperation between social forces, economic groupings and regions that combine democracy with collective mobilization will make it possible to redefine the boundaries between the public and the private, without sacrificing or indefinitely postponing the time for equality, and will create the conditions, this time within the terms of the democratic constraint, for a virtuous dialogue between accumulation and redistribution, of the kind that President Lázaro Cárdenas ventured to attempt at the head of the popular coalition which covered the country and its revolution with glory.

What we need to do, if we are to exit this hybrid labyrinth of "open solitude" which we are currently in (but which is a baroque continuation of the one sketched out for us by Octavio Paz), where modernity has become confused with the most ingenuous and insubstantial of cosmopolitanisms, is, if I may paraphrase Alfonso Reyes, to join in delineating, "as a possible field in which to achieve a more equal justice, a better understood freedom (...) the dreamed-of Republic, a Utopia" (Martínez, 2012). 


\section{VII}

\section{Conclusions}

The discords emerging from globalization and exacerbated by the crisis between external opening, State and national sovereignty, and democracy need to be addressed as a matter of urgency. These strains are acting in complex social contexts rent by inequality; in the face of all this, it is indispensable to restore development as a core, all-encompassing process. These are structural, valuerelated and ideological constraints that the planet needs to deal with to make way for evolved configurations in the economic and political order that create the right conditions for the search for new ideas and utopias organized around (and underpinned by) development.

All the institutional evolution and reforms required for a restored development entail an explicit acceptance of this as a complex political and social process, as well as an economic one. Whatever idea of development may come out of this dialectic cannot ignore the preponderant role to be played by policy and the State in its implementation, which is why the idea of social change and the imperative need to take democratic learning and teaching on board as irreplaceable features of the whole process need to be central to a historical and contemporary idea of development.

This is the context in which strategies and policies will have to be settled upon, as well as the different options for engaging in the global economy that arise, or should do, for nations striving to appropriate the idea of development as a reality and as a utopia.

\section{Bibliography}

Anguiano, Eugenio (2012), Mercados financieros internacionales. Su historia, evolución y crisis, Mexico City, National Autonomous University of Mexico (UNAM).

Bobbio, Norberto (1991), The Age of Rights, Cambridge, Polity.

Bottomore, Tom and T.H. Marshall (2005), Ciudadanía y clase social, Buenos Aires, Editorial Losada.

Carpizo, Jorge (2012), "El estado de los derechos de la justicia social", Revista Latinoamericana de Derecho Social, No. 14, Mexico City, National Autonomous University of Mexico (UNAM), January/June.

Cortina, Adela (2013), "Cómo cambiar la tendencia", El país, 23 January.

(2007), "Development Ethics: a Road to Peace", Working Paper No. 339, The Helen Kellogg Institute for International Studies, May [online] https://kellogg.nd.edu/publications/ workingpapers/WPS/339.pdf.

Dosman, Edgar (2011), "El regreso de Raúl Prebisch", Homenaje a Raúl Prebisch (1901-1986) (LC/G.2499), Alicia Bárcena, Edgar Dosman and Osvaldo Súnkel, Santiago, Chile, Economic Commission for Latin America and the Caribbean (ECLAC) [online] http://www.eclac.org/publicaciones/xml/9/48009/ HomenajeRaulPrebisch-Osvaldo.pdf. (2001), "Markets and the State in the evolution of the 'Prebisch manifesto"', CEPAL Review, No. 75 (LC/G. 2150-P), Santiago, Chile, December.

ECLAC (Economic Commission for Latin America and the Caribbean) (2012), Structural Change for Equality: An Integrated Approach to Development (LC/G.2524(SES.34/3)), Santiago, Chile.

(2010), Time for equality: closing gaps, opening trails (LC/G.2432(SES.33/3)), Santiago, Chile.

(2000), Equity, Development and Citizenship (LC/G.2071/ Rev.1-P), Santiago, Chile. United Nations publication, Sales No. E.00.II.G.81.

Fajnzylber, Fernando (1992), "Industrialización en América Latina: De la caja 'negra' al casillero vacío", Nueva Sociedad, No. 118, March/April.

Ferrer, Aldo (2010), "Raúl Prebisch and the dilemma of development in a globalised world", CEPAL Review, No. 101 (LC/G.2455-P), Santiago, Chile, August.
Furtado, Celso (2004), Revista Pesquisa, No. 106, State of São Paulo Research Foundation (FAPESP), December [online] http:// revistapesquisa.fapesp.br/es/2004/12/01/la-fantasia-deshecha/.

Galbraith, John Kenneth (2011), La cultura de la satisfacción, Madrid, Ariel.

Halperin, Tulio (2008), "ECLAC in its historical setting", CEPAL Review, No. 94 (LC/G.2357-P), Santiago, Chile.

Martínez, José Luis (2012), América en el pensamiento de Alfonso Reyes, Mexico City, Fondo de Cultura Económica.

Moreno Brid, Juan Carlos (2013), "Política macroeconómica para el desarrollo", EconomíaunAm, No. 30, Mexico City, National Autonomous University of Mexico, September/December.

Ocampo, José Antonio (2011), "Macroeconomy for development: countercyclical policies and production sector transformation", CEPAL Review, No. 104 (LC/G.2498-P), Santiago, Chile, August.

(2001), "Retomar la agenda del desarrollo", Configuraciones, No. 5-6, Mexico City, Institute of Studies for Democratic Transition, October/December.

Polanyi, Karl (1992), The Great Transformation. The Political and Economic Origins of Our Time, Mexico City, Fondo de Cultura Económica.

Prebisch, Raúl (1963), Towards a Dynamic Development Policy for Latin America, Mexico City, Fondo de Cultura Económica.

Ros, Jaime (2013), "Repensar el desarrollo económico, el crecimiento y las instituciones", EconomíaUnAM, No. 30, Mexico City, National Autonomous University of Mexico (UNAM), September/December.

Rosanvallon, Pierre (1989), "Development of Keynesianism in France", The Political Power of Economic Ideas: Keynesianism across Nations, Peter Hall (ed.), New Jersey, Princeton University Press.

Sen, Amartya (2003), Presentation at the International Seminar on Ethics and Development, Inter-American Development Bank.

Smith, Adam (1776), An Inquiry into the Nature and Causes of the Wealth of Nations, London, Methuen \& Co.

UNDP (United Nations Development Programme) (2004), Democracy in Latin America: Towards a Citizens' Democracy, New York.

Wolfe, Marshall (1976), El desarrollo esquivo, Mexico City, Fondo de Cultura Económica. 